\title{
Dynamic Behaviour of Raft Foundation for Tall building with Variable Subsoil
}

\author{
G.S. Doiphode Pratik Saraiya
}

\begin{abstract}
Structures are often constructed on layers of soil unless bedrock is very close to the ground surface. When the ground is stiff enough, the dynamic response of the structure will not be influenced significantly by the soil properties during the earthquake, and the structure can be analysed under the fixed base condition. When the structure is resting on a flexible medium, the dynamic response of the complete structure will be different from the fixed base condition, where the interaction between the soil and the structure has to be incorporate. This behavioural difference because of the phenomenon commonly referred to as Soil-Structure Interaction (SSI), which if not considered in analysis and design properly; the accuracy in assessing the structural safety, response for earthquake excitation could not be reliable solution. Hence evaluation of the site, specific effect of soil stiffness on structure becomes important to understand behaviour of structure. Flexibility of soil increases natural period of structure, which basically turn changes the seismic response of structure. The interaction among structure, their foundation and soil media below foundation alter the actual behaviour of structure. Here G+25 storey building is modelled and analysed, employing Finite Element Method adopting Commercial code SAP2000 V19 under fixed base (no soil-structure interaction) and flexible base considering soil-structure interaction. An attempt has been made to evaluate the effect of soil structure interaction of super structure by considering the systematic parameters like time period, lateral displacement, storey drift, bending moment in dual global structural axis i.e., $X-X$ and $Y-Y$ direction.
\end{abstract} model, Seismic Response, time period, bending moment, lateral displacement, storey drift, SAP2000 V19

\section{INTRODUCTION}

The problem of soil-structure interaction in the seismic analysis and design of structures has become increasingly important, as it may be inevitable to build structures at locations with less favourable and compatible geotechnical conditions in seismically active regions. The 28 December 1989 Newcastle (Australia) earthquake killed and injured over 150 people and damage bill was about \$4 billion. Recently, a similar disaster hit Haiti on 12 January 2010 causing over 200,000 deaths, and leaving over 3 million

Revised Manuscript Received on December 25, 2020.

* Correspondence Author

Dr. G. S. Doiphode*, Applied Mechanics \& Structural Engineering Department, Faculty of Technology \& Engineering. The Maharaja Sayajirao University of Baroda, Vadodara, Gujarat-State, India. Email :gsdoiphode-appmech@msubaroda.ac.in

Pratik Saraiya, PG Student, Applied Mechanics \& Structural Engineering Department, Faculty of Technology \& Engineering. The Maharaja Sayajirao University of Baroda, Vadodara, Gujarat-State, India. Email: pratiksaraiya7@gmail.com

(C) The Authors. Published by Blue Eyes Intelligence Engineering and Sciences Publication (BEIESP). This is an open access article under the CC BY-NC-ND license (http://creativecommons.org/licenses/by-nc-nd/4.0/)
Keywords: Raft foundation, soil-structure interaction, Winkler

people homeless. The similarity of these two earthquakes is that both are intra-plate earthquakes occurring in the interior of a tectonic plate. In both cases, many mid-rise buildings (approximately 5-15 stories) were severely damaged [1]. The scarcity of land insists engineers to construct major structures over soft deposits. Therefore, there is a need to design structures safely, but not costly against natural disasters such as earthquakes. Effects of dynamic soil-structure interaction under extreme loads due to strong earthquakes are significant for many classes of structures and it must be included seriously precisely in the design procedure. Soil-structure interaction (SSI) includes a set of mechanisms accounting for the flexibility of the foundation beneath a given structure which resulting in modifying the ground motion near the foundation compared to the free-field. It determines the actual loading experienced by the soil-structure system resulting from the free-field seismic ground motions [2]. The seismic excitation experienced by structures is a function of the earthquake characteristics, travel path effects, local site effects, and soil-structure interaction effects respectively. The result of the first three of these factors can be summarized as free-field ground motion. Structural response to the free-field motion is influenced by SSI. Accelerations within the structure are affected by the flexibility of the foundation support and the difference between foundation support and free-field motions. Consequently, an accurate assessment of the inertial forces and displacements in structures requires a rational treatment of SSI effects[3],[7]. For determining the seismic response of building structures, it is a common practice to assume the structure is fixed at the base. However, this is a gross assumption, since flexibility of the foundation could be overlooked and underestimated in this case. This assumption is realistic only, when the structure is founded on solid rock[4]. The main concept of site response analysis is that the free field motion is dependent on the properties of the soil profile including stiffness of soil layers. The stiffness of the soil deposit can change the frequency content and amplitude of the ground motion. Likewise, on the path to the structure, wave properties might be changed due to the stiffness of the foundation. In general, the subsoil foundation response subjected to seismic ground motion has been dictated by the soil attributes, the soil conditions, and the characteristics of the earthquake. So, here this study is to propose a simplified but practical design procedure which enables structural engineers to consider detrimental effects of soil structure interaction in seismic design of building frames to ensure the design safety and reliability. The paper comprises study of the behaviour of tall structure resting on different types of subsoil with Raft foundation during seismic excitation and understanding an effect of subsoil on the behaviour of tall building by Time History Analysis.
Blue Eyes Intelligence Engineering and Sciences Publication (C) Copyright: All rights reserved.

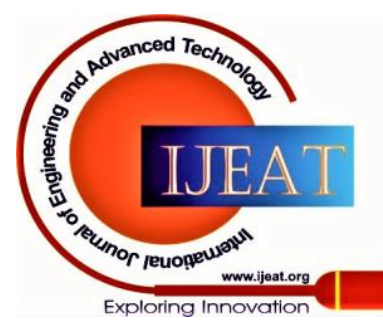




\section{Dynamic Behaviour of Raft Foundation for Tall building with Variable Subsoil}

\section{MODELLING}

Soil structure interaction effect on tall building with raft foundation under seismic load is investigated.

The time history analysis of tall building has been done by subjecting the whole system to earth quack ground motion (Bhuj EQ data) using SAP 2000 V19 software. The details of the tall building and data of three different soil for this study is shown in Fig. 1.



Fig. 1. Plan

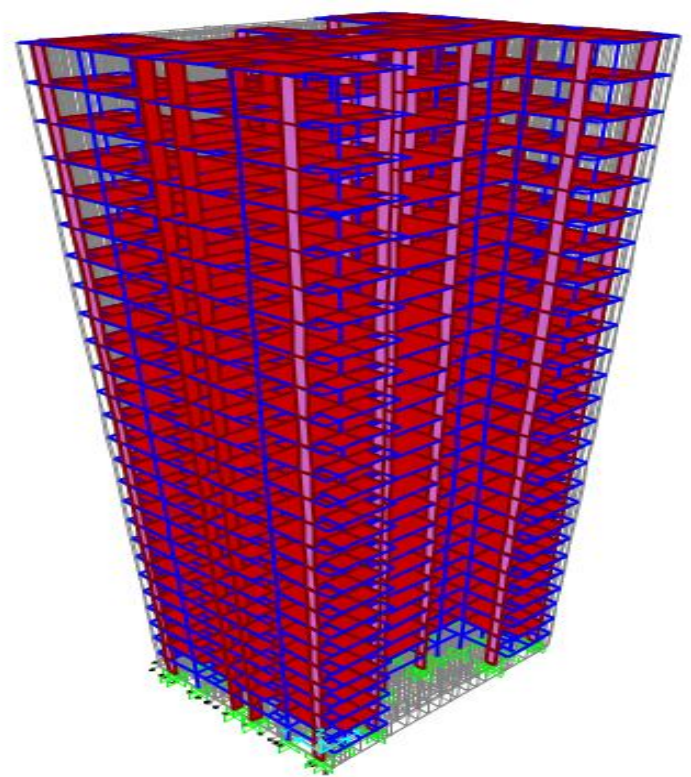

Fig. 2. 3-D view with Fixed Base
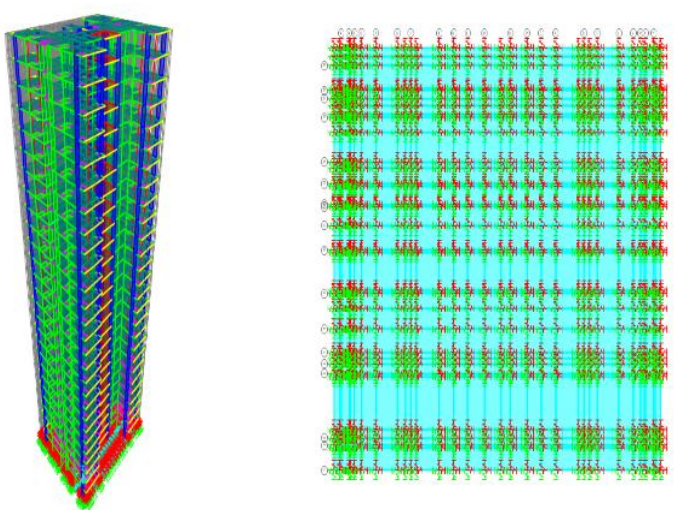

Fig. 3. 3-D view with Raft Foundation

\section{PROBLEM STATEMENT}

Total three numbers of $(G+25)$ RCC tall building structure models with rigid base and Raft Foundation resting on three varying types of soil ranging from soft to stiff has been carried out. Complete building is subjected to acceleration time history of BHUJ earthquake ground motion. Here, soil is idealized as a Winkler model and prescribed ground motion is used for global soil structure interaction analysis. The necessary deta is given below in Table I.

Table - I: Parameters

\begin{tabular}{|c|c|}
\hline \\
\hline Location & Surat (Seismic Zone III) \\
\hline Type of structure & RC Framed structure \\
\hline No. of Storey & $G+25$ \\
\hline Height of building & $81.500 \mathrm{~m}$ \\
\hline Storey Height & $3.2 \mathrm{~m}$ \\
\hline Floor Thickness & $130,150,250 \mathrm{~mm}$ \\
\hline Thickness of Shear Wall & $\begin{array}{c}\text { 250, } 300 \mathrm{~mm} \\
\text { (IS 13920: 2002) }\end{array}$ \\
\hline \multicolumn{2}{|c|}{ Material } \\
\hline Unit Weight of Concrete & $25 \mathrm{kN} / \mathrm{m}^{3}$ \\
\hline Unit Weight of Masonry & $20 \mathrm{kN} / \mathrm{m}^{3}$ \\
\hline Grade of Material & $\begin{array}{c}\text { M25, M30, M40, HYSD415 and } \\
\text { HYSD500 }\end{array}$ \\
\hline \multicolumn{2}{|r|}{ Load } \\
\hline Floor Finish Load & $1.5 \mathrm{kN} / \mathrm{m}^{2}$ \\
\hline Outer Wall Load & $\begin{array}{c}14 \mathrm{kN} / \mathrm{m} \\
\text { (230 mm Thick) }\end{array}$ \\
\hline Inner Wall Load & 7 kN/m (115 mm Thick) \\
\hline Live Load & $\begin{array}{c}3 \mathrm{kN} / \mathrm{m}^{2} \\
\text { (IS } 875 \text { Part II Table I) }\end{array}$ \\
\hline Earthquake Load & As Per IS 1893 \\
\hline Seismic Zone & III $(\mathrm{Z}=0.16)$ \\
\hline Importance Factor & $\begin{array}{c}1.2 \text { (IS 1893(Part - I): } 2016 \\
\text { Table 8) }\end{array}$ \\
\hline $\begin{array}{l}\text { Response Reduction } \\
\text { Factor }\end{array}$ & $\begin{array}{l}5 \text { (Special Moment Resisting } \\
\text { Frame, IS 1893(Part - I): } 2016 \\
\text { (Table 9) }\end{array}$ \\
\hline \% IL to Be Considered & $\begin{array}{c}\text { 50\% (IS 1893(Part - I): } 2016 \\
\text { Table 10) }\end{array}$ \\
\hline Load Combination & $\begin{array}{l}\text { As Per IS 1893(Part - I): } 2016 \\
\text { Clause 6.3.2.2 }\end{array}$ \\
\hline \multicolumn{2}{|c|}{ Foundation data (Raft Foundation) } \\
\hline Thickness of Raft & $800 \mathrm{~mm}$ \\
\hline Area of Raft & $683.3983 \mathrm{~m}^{2}$ \\
\hline \multirow{3}{*}{$\begin{array}{c}\text { Modulus of Sub Grade } \\
\text { Reaction of Soil } \\
\text { (Laboratory) }\end{array}$} & $\mathrm{K}_{1}=26576.0215 \mathrm{kN} / \mathrm{m}^{3}$ \\
\hline & $\mathrm{K}_{2}=39618.866 \mathrm{kN} / \mathrm{m}^{3}$ \\
\hline & $\mathrm{K}_{3}=56486.304 \mathrm{kN} / \mathrm{m}^{3}$ \\
\hline
\end{tabular}

\section{RESULTS AND DISCUSSIONS}

Published By:

Blue Eyes Intelligence Engineering

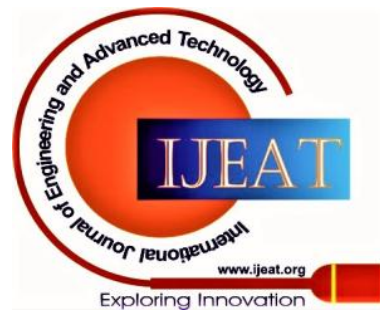


A variation in time period due to soil flexibility is depicted in Fig.4 which also highlights the comparison between fixed and flexible base with two methods, i.e., equivalent static and time history analysis[6],[8].Fig. 5 showsZ displacement of Raft foundation in both EquivalentStatic Analysis and Time History Analysis respectively

[9].

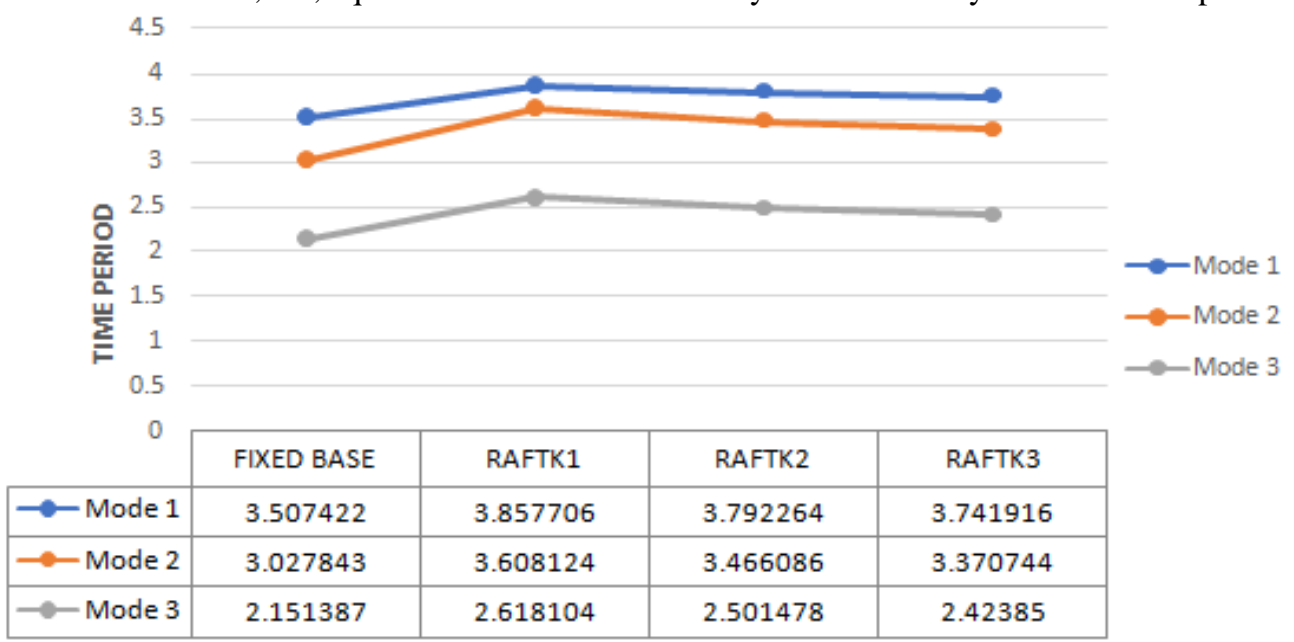

Fig. 4. Variation of time period $v / s$ foundation types

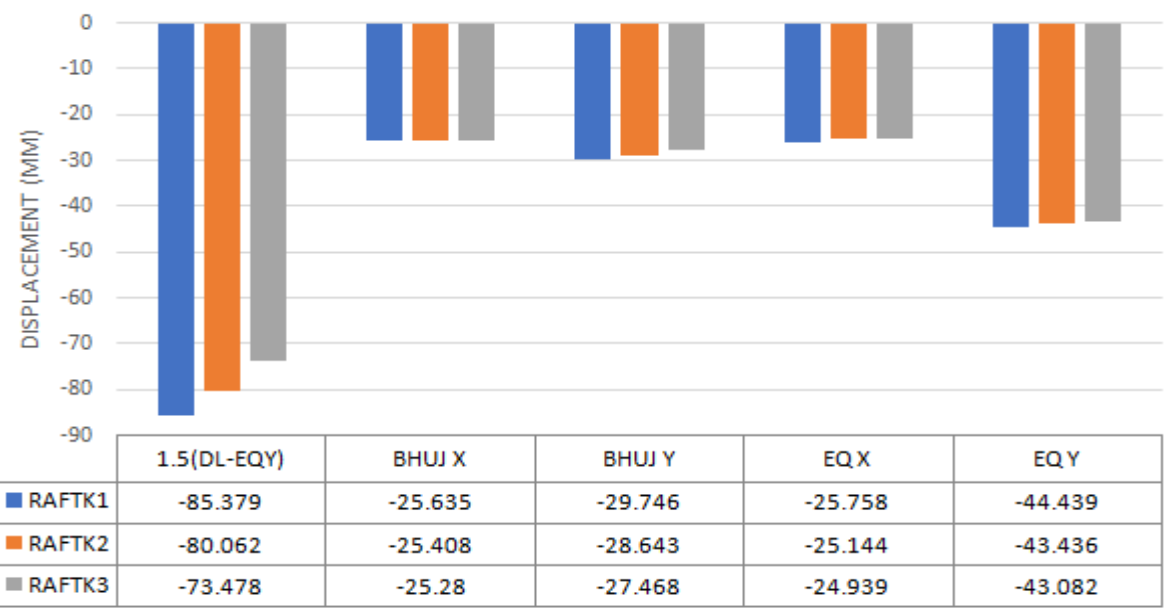

Fig. 5. Maximum displacement of Raft Foundation in Z-Direction

Lateral displacement of tall building in both X - Direction and Y - Direction is depicted in Fig.6, 7, 8 and 9 respectively for both Fixed base and Raft foundation with various type of soil conditions for Static Equivalent Analysis and Time History Analysis.



Fig. 6. Maximum Lateral displacement in X-Direction for EQ X

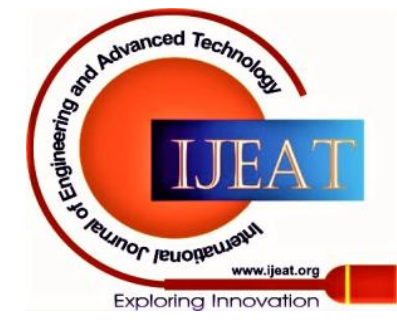




\section{Dynamic Behaviour of Raft Foundation for Tall building with Variable Subsoil}

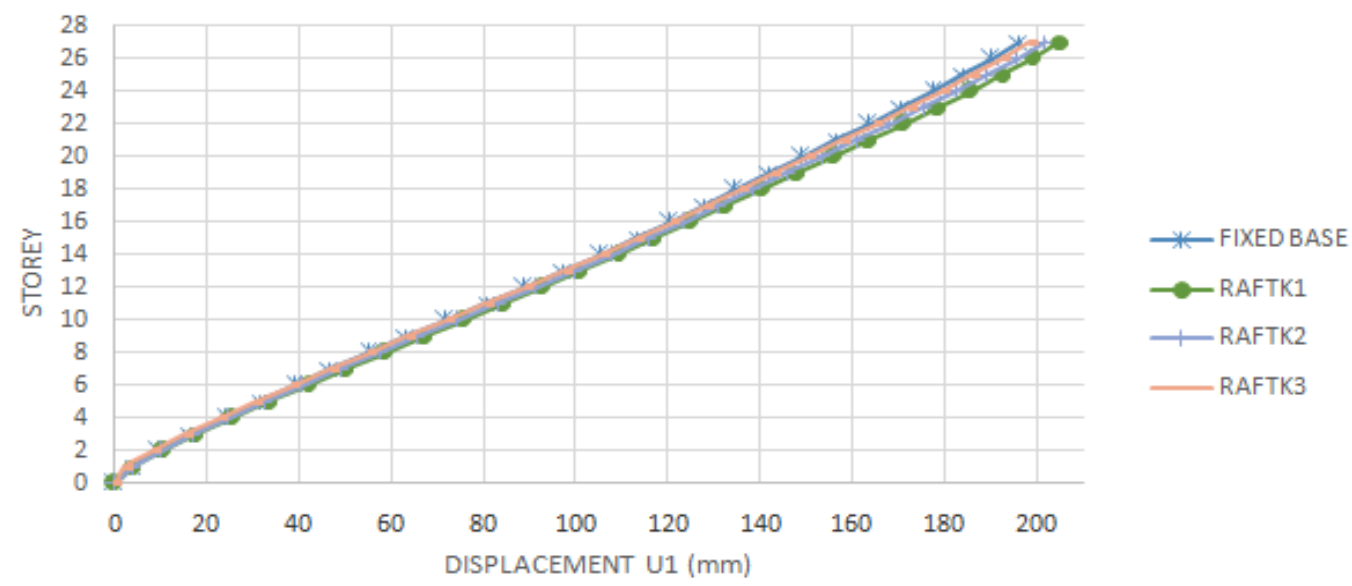

Fig.7. Maximum Lateral displacement in X-Direction for BHUJ X

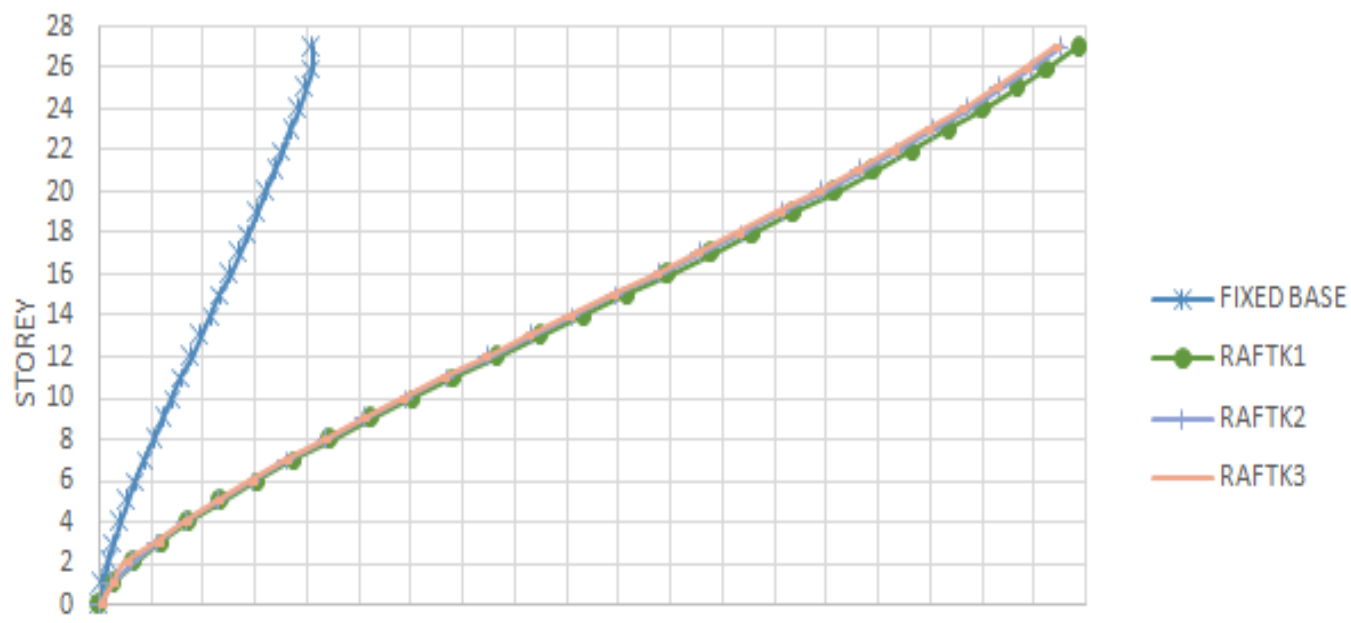

0255075100125150175200225250275300325350375400425450475 DISPLACEMENT U2 $(\mathrm{mm})$

Fig.8. Maximum Lateral displacement in Y-Direction for EQ Y

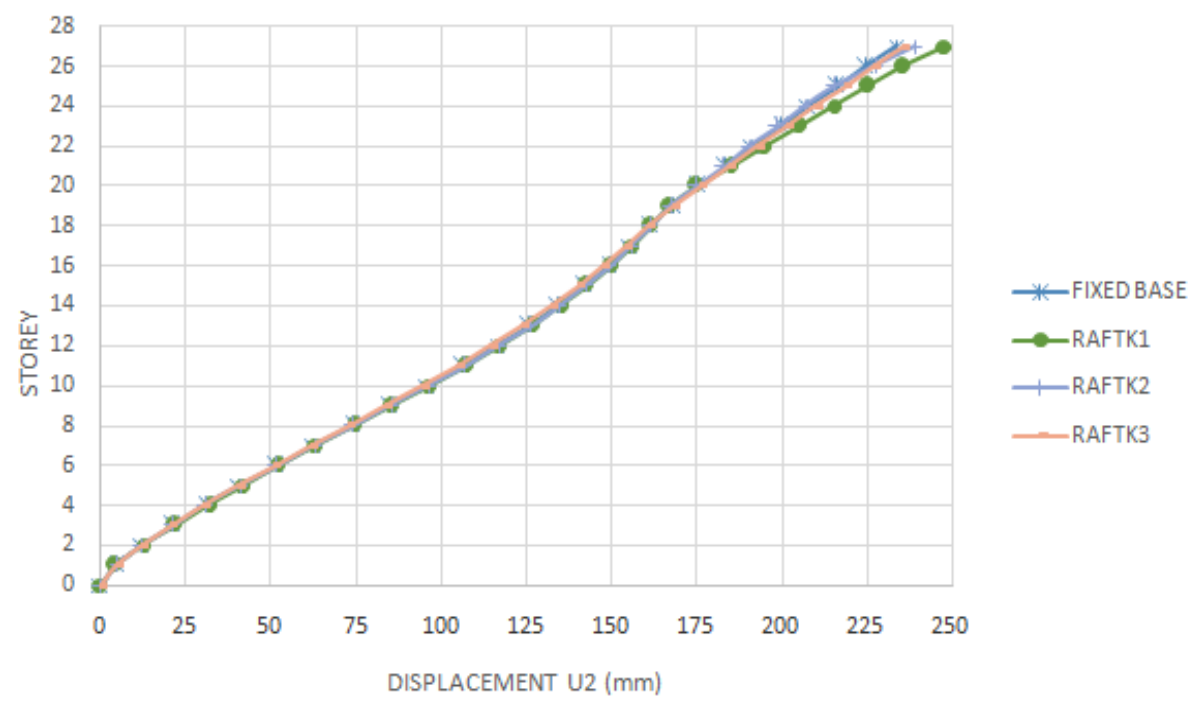

Fig. 9. Maximum Lateral displacement in Y-Direction for BHUJ Y

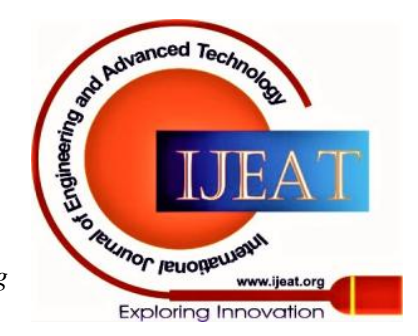


Fig.10 and Fig.11 shows Maximum Bending Moment (M11 and M22) of raft foundation of tall building along both X Direction and Y - Direction by using Static Equivalent Analysis and Time History Analysis, while Fig.12. shows torsional moment (M12) for raft foundations about Z axis by using same methodological approach.

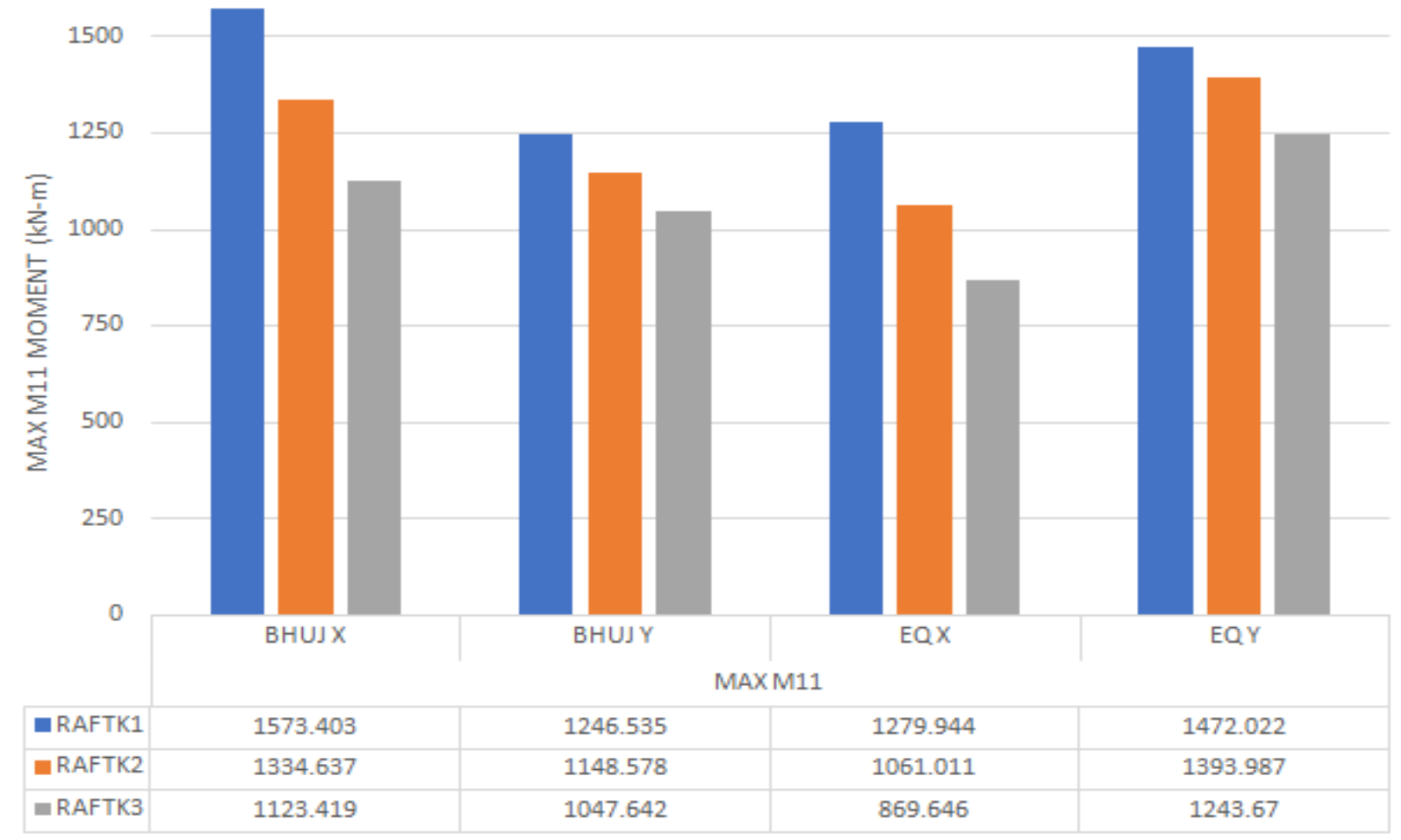

Fig.10. Maximum Bending Moment (M11) along X-Direction

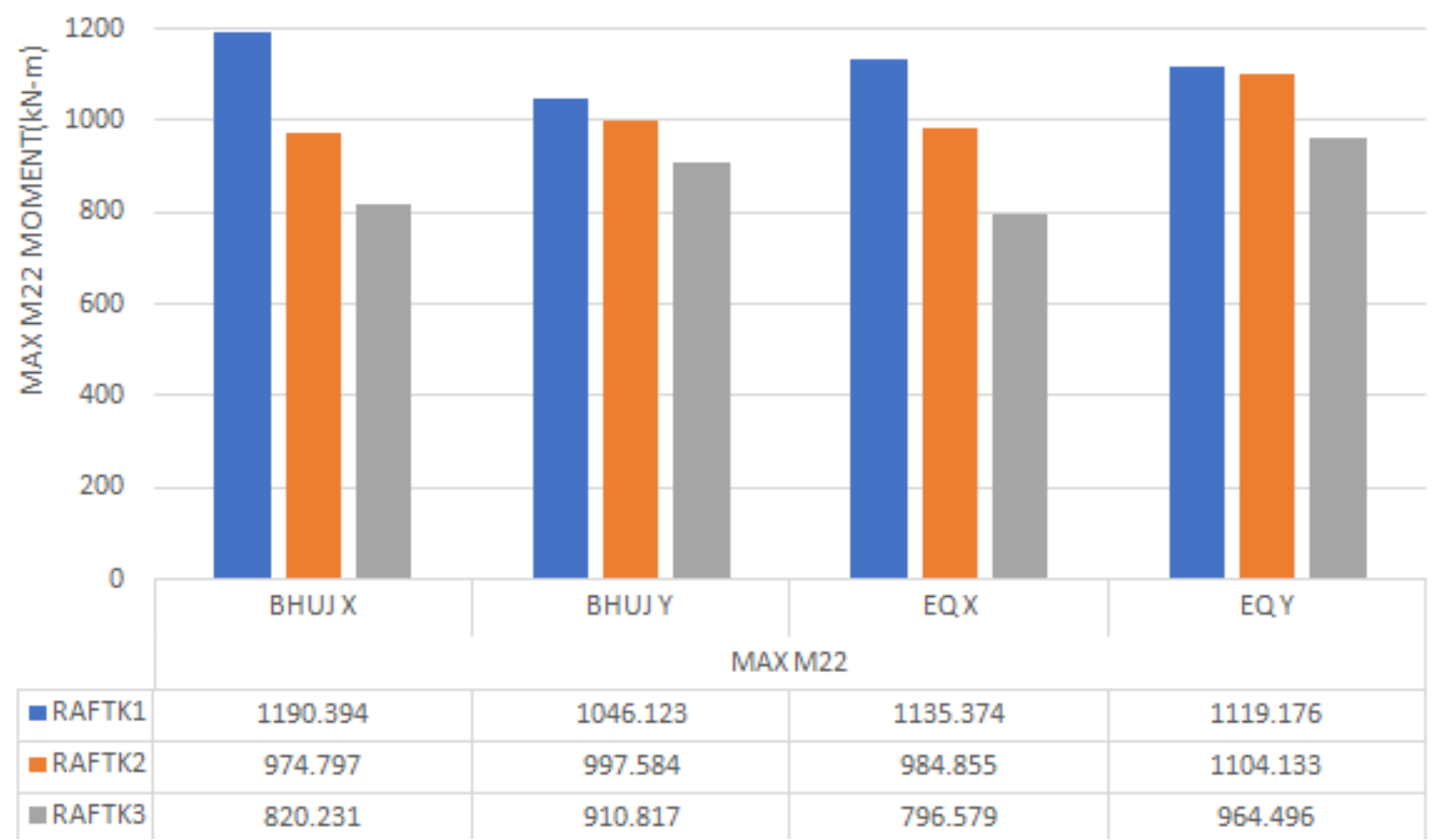

Fig.11. Maximum Bending Moment (M22) along Y-Direction

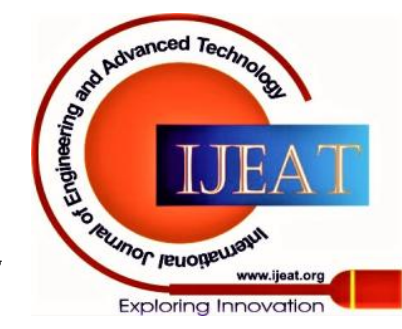




\section{Dynamic Behaviour of Raft Foundation for Tall building with Variable Subsoil}

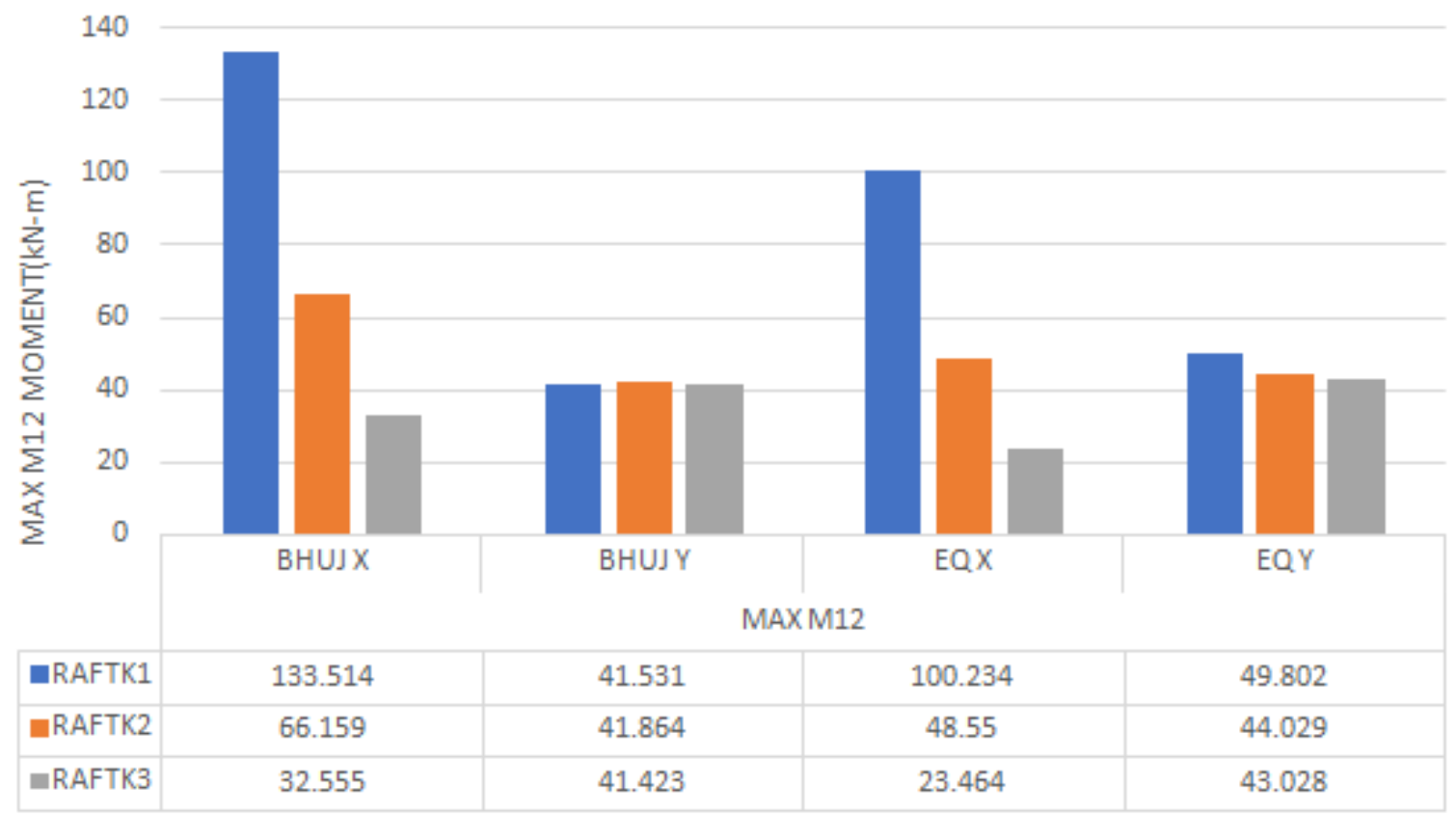

Fig. 12. Maximum Torsional Moment (M12) along Z - Direction

\section{CONCLUSION}

Research attempts to study the effect of soil-structure interaction on Tall Building with raft foundation which provides complete idea of change in various seismic response quantities due to consideration of flexibility of soil below the foundation.

1.The time period of the tall building on the different soils with raft foundation is increased as compared with the fixed conditions. The increasing trend of time period was due to flexibility of soil medium below the foundation.

2. The displacement of Raft foundation in Z- Direction increases in both Static Equivalent Analysis and Time History Analysis as Soil flexibility increases.

3. Maximum Lateral displacement of tall building in $\mathrm{X}$ Direction and Y - Direction increases in both Static Equivalent Analysis and Time History Analysis cases.

4. Maximum Bending Moment (M11 and M22) of Raft Foundation of tall building along both $\mathrm{X}$ - Direction and $\mathrm{Y}$ - Direction increases in both Static Equivalent Analysis and Time History Analysis.

5. Due to variation in subgrade reactions Maximum Torsional Moment (M12) of Raft Foundation of tall building increases in both Static Equivalent Analysis and Time History Analysis.

\section{REFERENCES}

1. J. D Patil, S. A Vasanwala and C.H Solanki "An experimental investigation on behaviour of pile raft foundation",International Journal of Geomatics and Geosciences. ISSN:0976-4380, pp. 139-145, Vol. 5, No.2,2014

2. M.N Kuladeepu andG Narayana, “ Soil Structure Interaction effect on dynamic behaviour of 3D building frame with raft footing" International Journal of Research in Engineering and Technology. ISSN:2319-1163, pp.34-43, Vol.4, No5,2015.

3. M. zubair and B. R Shilpa "A Parametric "Study of Soil structure interaction of raft foundation by using dynamic analysis" International Journal of Engineering Science Invention Research \& Development.ISSN: 2349-6185,pp. 46-51, Vol.3, No.1, 2016.

4. R.Radhika, S.P.Jeyapriya and P.Soundrapandiyan"Parametric Study and Numerical analysis of piled raft foundation on soft clay" International
Journal For Research In Emerging Science And Technology. ISSN:2348-7607, pp.95-99,Vol. 2, No.4, April 2015

5. N. Kumar S, J V Praveen "Study of Soil structure interaction effect on multi-storey RC frame structures resting over raft foundation under earthquake cased excitations. International Journal of Civil and Structural Engineering Research ISSN:2348-7607,pp(95-102) Vol.4, No. 1. Jan 2015.

6. H. J. Shah, S. K. Jain "Design example of a six storey building "Document No: IITK-GSDMA-EQ26-V3.0.

7. IS 2911-Part I(2010) Indian Standard Code of design and construction of pile foundations.

8. IS: 1904 - 1986 Indian Standard Code of practice for design and construction in soil - General requirements.

9. IS: 2950 -Part I - 1981 Indian Standard Code of design and construction of Raft foundations .

\section{AUTHORS PROFILE}



Dr. G. S. Doiphode working as Associate Professor in AppliedMechanics \& Structural Engineering Department. Faculty of Technology \& Engineering, The Maharaja Sayajirao University of Baroda, Vadodara Gujarat-State (India). He have published 30 Research publications in International and national journals and conferences. He has tota 24 years of teaching experience at UG and PG Level till date.

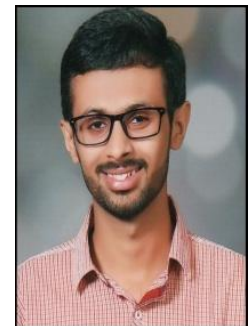

Mr. Pratik Saraiyahas completed B. E. civil from Government College of Engineering, Surat Gujarat-State in 2015. He has completed his Master of Structural Engineering at faculty of Technology \& Engineering. The Maharaja Sayajirao University of baroda, Vadodara-Gujrat (India) in July 2018. Presently working as Deputy Executive Engr in Surat Municipal Corporaton, Surat

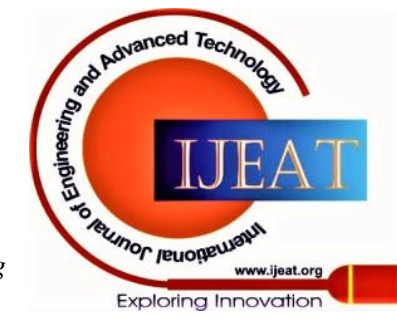

